Sains Malaysiana 50(11)(2021): 3171-3179

http://doi.org/10.17576/jsm-2021-5011-02

\title{
Impacts of $\kappa$-Oligocarrageenan Application on Photosynthesis, Nutrient Uptake and Bean Yield of Coffee (Coffea robusta)
}

(Kesan Pengaplikasian K-Oligokaragenan pada Fotosintesis, Pengambilan Nutrien dan Hasil Biji Kopi (Coffea robusta))

\author{
Pham Trung San, Chau Minh Khanh, Huynh Hoang Nhu Khanh*, Truong Anh Khoa, Nguyen Ho- \\ Ang, Pham DUC THINH \& THANH-DANH NGUYEN
}

\section{ABSTRACT}

$\kappa$-Oligocarrgeenan (OC) is well known as an effective and green plant growth promoter and elicitor. However, its effect on coffee plant has not been investigated so far. This study aimed to examine the impacts of OC on biophysical activity, vegetative growth and productivity of coffee plant (Coffea robusta). OC with average molecular weight (AMW) of $4.0 \mathrm{kDa}$ was prepared by depolymerization of carrageenan using ascorbic acid. Field experiments were conducted by foliar spray four times per year at various OC concentrations (50, 100, 150, 200, and 250 ppm) for three years (2017-2019). The results showed that OC promoted growth of coffee plant in all tested concentrations, and an optimized concentration was found at $150 \mathrm{ppm}$ which showed a significant increase compared to the control plant in total chlorophyll (24.79\%), carotenoid (31.65\%), uptakes of $N(15.66 \%), P(15.81 \%)$, and K (22.25\%) minerals in leaves, crop yield (19.80\%) and bean size (13.10\%). Therefore, OC is potentially promising to apply as a promoter to enhance yield of crops for sustainable coffee plantation.

Keywords: Bean yield; coffee plant; concentration; oligocarrageenan; promoter

\section{ABSTRAK}

$\kappa$-Oligokaragenan (OC) terkenal sebagai penggalak pertumbuhan tanaman hijau dan pengelisit yang berkesan. Walau bagaimanapun, kesannya terhadap kilang kopi belum dikaji setakat ini. Kajian ini bertujuan untuk mengkaji kesan OC terhadap aktiviti biofizik, pertumbuhan vegetatif dan produktiviti tanaman kopi (Coffea robusta). OC dengan berat molekul purata $(A M W) 4.0 \mathrm{kDa}$ disediakan dengan penceraian polimer karagenan menggunakan asid askorbik. Uji kaji lapangan dilakukan dengan semburan daun empat kali setahun pada pelbagai kepekatan OC (50, 100, 150, 200 dan 250 ppm) selama tiga tahun (2017-2019). Hasil kajian menunjukkan bahawa OC mendorong pertumbuhan tanaman kopi pada semua kepekatan yang diuji dan kepekatan yang optimum didapati pada 150 ppm yang menunjukkan peningkatan yang signifikan berbanding kilang kawalan dalam mineral jumlah klorofil (24.79\%), karotenoid (31.65\%), pengambilan $N$ (15.66\%), P (15.81\%) dan K (22.25\%) dalam daun, hasil tanaman (19.80\%) dan saiz kacang (13.10\%). Oleh itu, OC berpotensi untuk diterapkan sebagai penggalak untuk meningkatkan hasil tanaman perkebunan kopi lestari.

Kata kunci: Hasil kacang; kepekatan; kilang kopi; oligokaragenan; penggalak

\section{INTRODUCTION}

Coffee is one of the most important crops in Vietnam with the current planted area of over 500,000 ha mostly in Central Highland. The annual coffee output is around 1.2 million tons as the second-highest yield in the world after Brazil. The consequent rise in productivity and quality for many years and abnormal changes of climate such as drought and heavy rain generate a significant demand on the use of chemical fertilizers. Coffee plant can leave $8 \%$ of chemical fertilizers in the soil (Salamanca-Jimenez et al. 2017). This leads to increase in the production cost and runoff of fertilizers polluting land and water and harming living environment of wildlife. Improvement of the productivity with minimizing used chemical fertilizers is considerable as the principal strategic goal of the sustainable coffee plantation. It can be achieved by alterative use of a promoter, well-known as natural substances which can enhance plant growth and nutrient uptake as well as reduce 
the dependency of plants on chemical fertilizers (Dias et al. 2017; Xu \& Geelen 2018).

In recent years, plant-derived promoters are gaining global attention to decrease the use of synthetic fertilizers (Zulfiqar et al. 2020). Numerous types of promoters from seaweed extracts have been used effectively. Among them, the oligosaccharides such as oligomers prepared from alginate, chitosan and carrageenan are increasingly used in the agriculture to promote growth and productivity of various floral and vegetal plants. It is an emerging technology to promote a green agriculture that balances between high profits and sustainability (Salachna et al. 2018).

$\kappa$-Oligocarrgeenan (OC), oligosaccharides derived from seaweed carrageenans, contains several to a few dozen units of sulfated galactose, possessing a molecular weight of less than $10 \mathrm{kDa}$ (Xia et al. 2011). OC was reported to promote the growth and productivity of many food crops such as peanut (Bongalos et al. 2019), mungbean (Gatan et al. 2019), maize (German et al. 2020), and many other vegetal plants and also enhance plant defense against phytopathogens, insects, and even environmental stresses (Guilli et al. 2016; Stadnik \& Freitas 2014). To promote the plant growth, OC appears to act as promoting molecules that can induce expression of genes involving in various metabolisms relating to the plant growth at different physiological stages. OCs also induced increase in plant height, leaves biomass and leaves chlorophyll content in tobacco (Castro et al. 2012; Munoz et al. 2011), augmented trunk diameter of southern blue gum (González et al. 2013) and enhanced the level of plant hormones production (indole-3-acetic acid, and gibberellic acid) of radiate pine tree (Saucedo et al. 2015). For promoting the plant defense, OC serves as an elicitor molecule that binds to specific receptors in plant plasma membrane, subsequently inducing expression of the genes involving in toxin and secondary metabolites (Walling 2000). Besides, OC also enhances plant tolerance against unconditioned environmental stress, like drought and heavy rains. For instance, OCs proved to be the best elicitor on lemongrass to improve plant-water relation parameters, metabolism, antioxidant enzymes, contents of essential oils under drought-stress condition, promoting plant productivity under low chemical fertilization inputs, and low water usages (Singh et al. 2017).

Although OC is widely used to enhance productivity and quality of numerous crops, its application on coffee plant has not been reported in the literature. The aim of this study was to evaluate the effect of different OC concentrations on growth, crop yield and quality of robusta coffee plant (Coffea robusta) as well as study metabolism of nutrients in the plants by foliar application.

\section{MATERIALS AND Methods}

Oligocarrageenan was prepared from carrageenan using hot ascorbic acid $(0.2 \mathrm{M})$ at $90^{\circ} \mathrm{C}$ with the addition of $2 \%$ $\mathrm{H}_{2} \mathrm{O}_{2}$ in 120 min as previous report (San et al. 2020). OC with AMW of $4.0 \mathrm{kDa}$ was estimated by Gel Permeation Chromatography (GPC). The effect of OC was evaluated on coffee plants cultivated in field condition for three years (2017-2019).

The field experiment was carried in CuMgar, Daklak $\left(12^{\circ} 47^{\prime} 31^{\prime} \mathrm{N}\right.$ and $\left.108^{\circ} 04^{\prime} 35^{\prime} \mathrm{E}\right)$ with ferralsols soil, at $500 \mathrm{~m}$ in height than the seawater level. Characters of experimental soil including $\mathrm{N}(0.154 \pm 0.02 \%$, w/w $)$, $\mathrm{P}(0.156 \pm 0.015 \%, \mathrm{w} / \mathrm{w}), \mathrm{K}(0.094 \pm 0.02 \%, \mathrm{w} / \mathrm{w}), \mathrm{pH}$ $(5.28 \pm 0.34, \mathrm{w} / \mathrm{w})$, humidity $(32.6 \pm 2.7 \%, \mathrm{w} / \mathrm{w})$, humus $(3.32 \pm 0.628 \%, \mathrm{w} / \mathrm{w})$ and aerobic bacteria $\left(3.44 \times 10^{5} \pm\right.$ $\left.1.96 \times 10^{5} \mathrm{CFU} \mathrm{mg} \mathrm{mg}^{-1}\right)$ were analyzed. Meteorological data such as average air temperature in $2017\left(24.6^{\circ} \mathrm{C}\right), 2018$ $\left(24.2^{\circ} \mathrm{C}\right), 2019\left(24.8^{\circ} \mathrm{C}\right)$ and total rainfalls in $2017(1622$ $\mathrm{mm}), 2018$ (1630 mm), 2019 (1763 mm) were taken from the Tay Nguyen Regional Hydrometeorological Center. The rainfall data is plotted (Figure 1), and it showed that monthly precipitation in 2018 was unusual compared to the other years. No rain during January-February and then heavy rains during August-September were recorded in the years. Such climate could induce unusual data on coffee productivity.

The robusta coffee plants were planted according to the national standard guidance (10TCN478:2001 and 273/QD-TT-CCN). $10 \mathrm{~kg}$ of cattle manure and $0.5 \mathrm{~kg}$ of $\mathrm{P}_{2} \mathrm{O}_{5}$ was added to hole $(50 \times 50 \times 50 \mathrm{~cm})$ at 30 days preplanting. The 6-8 month-old plants were put in hole (30-35 $\mathrm{cm})$. Place between plants was $0.5 \mathrm{~m}$. The coffee plants were kept free of weeds to avoid weed-crop competition. The cattle manure (25-30 ton. ha $\left.^{-1}\right)$ was applied for each 2-3 years. The content of fertilizers was irrigated in first year was $\mathrm{N}\left(130 \mathrm{~kg} \mathrm{ha}^{-1}\right), \mathrm{P}\left(550 \mathrm{~kg} \mathrm{ha}^{-1}\right)$ and $\mathrm{K}(50 \mathrm{~kg}$ $\left.\mathrm{ha}^{-1}\right)$; second year was N (200 kg ha-1), P (550 kg ha' $)$ and $\mathrm{K}\left(150 \mathrm{~kg} \mathrm{ha}^{-1}\right)$ and third year was N (250 kg ha-1), P (550 $\left.\mathrm{kg} \mathrm{ha}^{-1}\right)$ and $\mathrm{K}\left(200 \mathrm{~kg} \mathrm{ha}^{-1}\right)$ and next year was N (260 kg $\left.\mathrm{ha}^{-1}\right), \mathrm{P}\left(95 \mathrm{~kg} \mathrm{ha}^{-1}\right)$ and $\mathrm{K}\left(200 \mathrm{~kg} \mathrm{ha}^{-1}\right)$. The fertilizers were applied four times per year.

For field trials, the experiments and assessments were carried out via the national standard guidance for perennials (10TCN 216:1995). Eight-year-old coffee plants were selected to investigate in three years (2017-2019). The experimental site comprised of 18 plots with average area of $180 \mathrm{~m}^{2}$ (20 plants) for each plot, and the experiment 


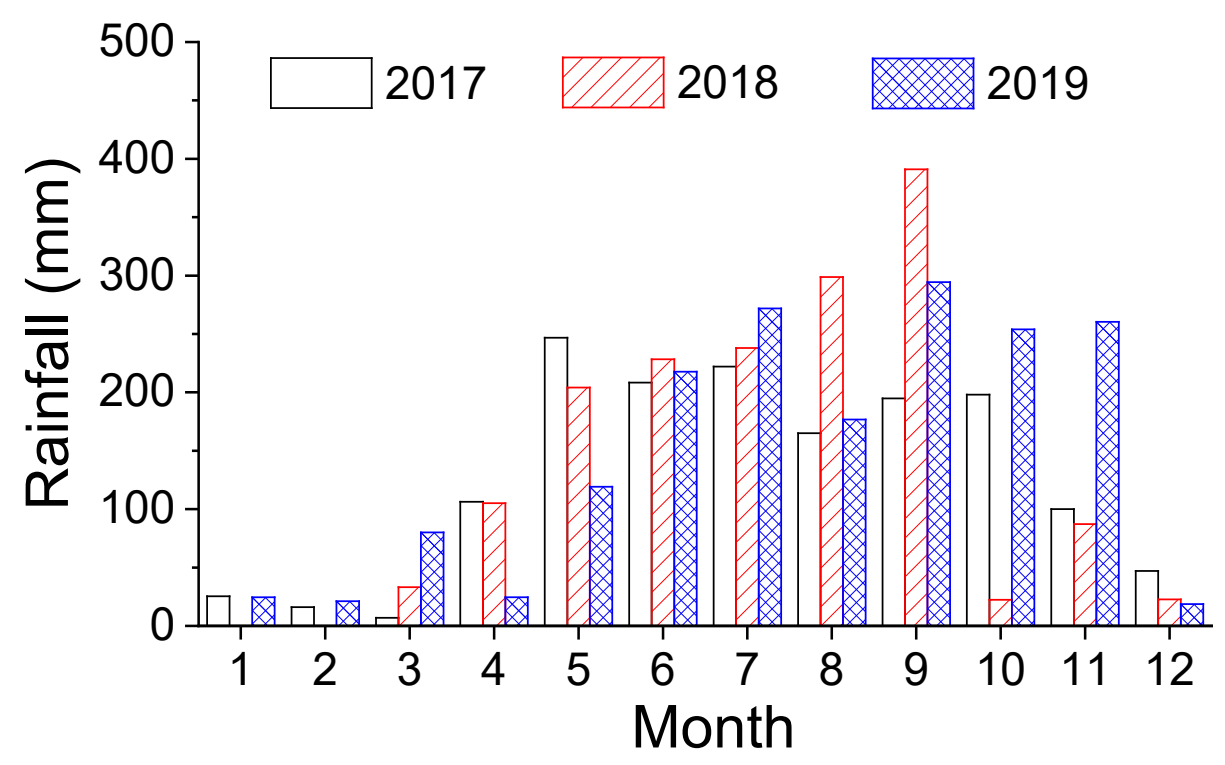

FIGURE 1. Monthly average precipitation in three years (2017-2019) in CuMgar, Daklak province, Vietnam. Data obtained from the Regional Hydrometeorological Center, Buon Ma Thuot city, Daklak Province

was conducted using a completely randomized block design with three replications. Foliar application of OCs was carried out four times per year starting in April with a period of 20 days during three experiment years at five various concentrations including 50,100,150,200, and $250 \mathrm{ppm}$. Plants applied with water acted as controls.

After 20 days counted from the last foliar application, the leaf samples were taken to evaluate contents of total chlorophyll, carotenoid, N, P and P. Fourth leaves couple on the primary preproductive branch of coffee tree were collected for investigation. Ten leaves per five plants in each plot were collected randomly. Leaves were dried and finely grounded into powder. Total chlorophyll and carotenoid contents in leaves were determined by Moran's method (Moran 1982) using UV/VIS spectrophotometer. For analysis of NPK content, the dried leaf powder was digested in sulfuric acid $\left(\mathrm{H}_{2} \mathrm{SO}_{4}, 98 \%\right)$ containing $30 \%$ $\mathrm{H}_{2} \mathrm{O}_{2}$. The $\mathrm{N}$ content in leaf sample was estimated by Kjeldahl method. The K content was analyzed by a flame photometer (Cottenie et al. 1982). P content was analyzed by colorimetric (molybdenum blue) method (Chapman \& Pratt 1962).

The vegetative development of the coffee trees was evaluated in four plagiotropic branches per tree (Jaramillo-Botero et al. 2010). Five plants in each plot were selected randomly. The branches were situated on the middle third of the trees, oriented to the north, south, east and west directions. The plagiotropic branch length was measured from the last fruit clump on the branch to the top of the branch. The number of productive nodes formed in each the plagiotropic brances counted from May to November.

Weight of fresh fruit was defined as weight for 100 fresh fruits of coffee which were determined by the following equation:

$$
\text { Weight of fresh fruit }(g)=\frac{1000}{n} \times 100
$$

where $n$ is number of fruits counted in $1 \mathrm{~kg}$ of coffee fruits. The values were determined three replications in each plot.

Ratio of fresh fruits (FF) to dry bean (DB) (FF/DB) was calculated from weight of fresh fruits and weight of dry bean in the plots at each applied OC concentration. For drying coffee beans, the fresh fruits harvested from each experimental plot were firstly dried to $13 \%$ moisture content, and then the dried coffee beans were obtained by using specialized coffee processing machines. Total yield per hectare were also calculated from the bean weight for each experimental plot. The size quality of coffee is determined by the Sieve method according to the national standard guidance for bean coffee (TCVN 4193-2005). 
Class A size of coffee is coffee beans with size $>6.3 \mathrm{~mm}$ (remaining on Sieve 16).

All the experiments were triplicated. Statistical analysis was performed using one-way analysis of variance (ANOVA) and followed by Duncan's multiple range test with triplicate. P-value $\leq 0.05$ considered as significance.

\section{RESULTS AND DISCUSSION}

\section{EFFECT OF OC ON CHLOROPHYLLS AND CAROTENOID}

The plant is evolved via various complex metabolic pathways to collect energy and form the metabolites necessary for the growth. In the present work, OC with AMW of $4.0 \mathrm{kDa}$ was sprayed on the leaves of the coffee plant at different concentrations for three years 20172019. For studying their effect on biophysical activity of plants, content of total chlorophylls, carotenoid and nutrient elements ( $\mathrm{N}, \mathrm{P}$ and $\mathrm{K}$ ) in leaves of coffee plant were evaluated by the laboratory analysis.

Figure 2 shows that the impact of OC indicated clear change of chlorophylls and carotenoid contents in coffee plant which depended on the applied concentrations of OC. The chlorophyll and carotenoid contents were increased when OC concentration was applied in the range of 0-200 ppm. These parameters were not significantly different between treatments 150 and $200 \mathrm{ppm}$ while a considerable decrease was observed for plants treated with concentration 250 ppm. The highest chlorophyll contents were achieved in plants treated with OC concentration at $150 \mathrm{ppm}$ which increased in total chlorophyll of $24.79 \%$ and carotenoid of $31.65 \%$ compared to the control. The data showed a slight change among the years. Increase in chlorophyll content compared to the control plants was found to be $23.04 \%$ in $2017,25.31 \%$ in 2018 , and $26.33 \%$ in 2019 . This indicates that the coffee plants treated with OC seem to be healthier over the years.

The chlorophyll and carotenoid are very important in photosynthesis to produce sugars and organic molecules by fixation of $\mathrm{CO}_{2}$ and water. The increase in chlorophyll content in plants by application of OC has been reported previously. For examples, application of OC increased in chlorophyll a (20\%) and chlorophyll b $(30 \%)$ in tobacco plants (Castro et al. 2012), total chlorophyll (16.6\%) in cape periwinkle and 12.8\%-3.8\% on wild mint (Naeem et al. 2012). Also, application of oligosaccharides derived from seaweed such as oligochitosan has been known to enhance the growth of coffee plant. The results showed that application of oligochitosan in abrabica coffee planted in the same experimental area (Daklak province) enhanced strongly the content of chlorophylls in the coffee leaves up to $46.38 \%$ compared to the control in green house condition, but increase only $15.36 \%$ in the field condition (Dzung et al. 2011). Result in this study showed that application of OC can enhance higher chlorophyll content in leaves of coffee than oligochitosan in field condition.
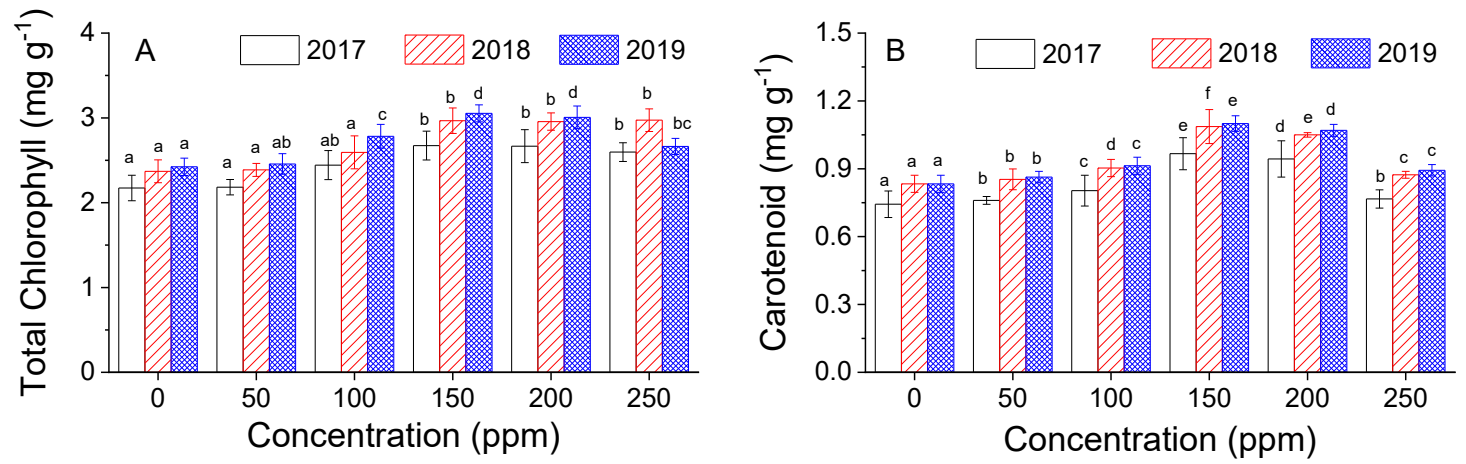

FIGURE 2. Influence of OC concentrations on total chlorophyll (A) and carotenoid (B) in coffee plant leaves for years 2017-2019. Bars represent mean values of three replicates \pm standard deviation. Different letters indicate significant differences $(\mathrm{P}<0.05)$

\section{EFFECT OF OC ON NUTRIENT UPTAKE}

Increase in chlorophyll and carotenoid contents can induce promotion of nutrient absorption. Similarly, NPK contents were significantly different in plants treated with OC at concentration 100-200 ppm compared to the control (Figure 3). It is noteworthy to know that nitrogen 
and phosphorus contents were increased significantly compared to the control but no significant difference among the treatments while potassium content of plants treated at low OC concentration (50 ppm) was not significantly different compared to the control. The highest value was also found in leaves of coffee plants treated at OC concentration at $150 \mathrm{ppm}$. NPK contents significantly increased by $11.6 \%, 16.7 \%$ and $22.0 \%$, respectively in $2017 ; 15.1 \%, 15.4 \%$ and $21.9 \%$, respectively in 2018 ; and $20.3 \%, 15.4 \%$ and $22.9 \%$, respectively in 2019 . This result was higher than that of oligochitosan application on coffee plant $(9.49 \% \mathrm{~N}, 11.76 \% \mathrm{P}$ and $0.98 \% \mathrm{~K}$ ) (Dzung et al. 2011). Caroll et al. (1994) found that the $\mathrm{N}$ and
$\mathrm{P}$ contents related closely to growth of tissue while $\mathrm{K}$ content played a major role in enzyme activation and keeping cell osmotic potentials but was not incorporated into plant tissues. Thus, increase in $\mathrm{N}$ and $\mathrm{P}$ uptakes of coffee plant treated with OCs may lead to promoting plant growth while increased $\mathrm{K}$ content making plant healthier may lead to improving of the crops yield (Bi et al. 2011; San et al. 2020). On the other hand, the increased nutrient content in the plant also proves the better capability of nutrient absorption from the soil in spite of the same amount of applied fertilizer, indicating that application of OC may reduce the amount of waste fertilizer in the soil environment.
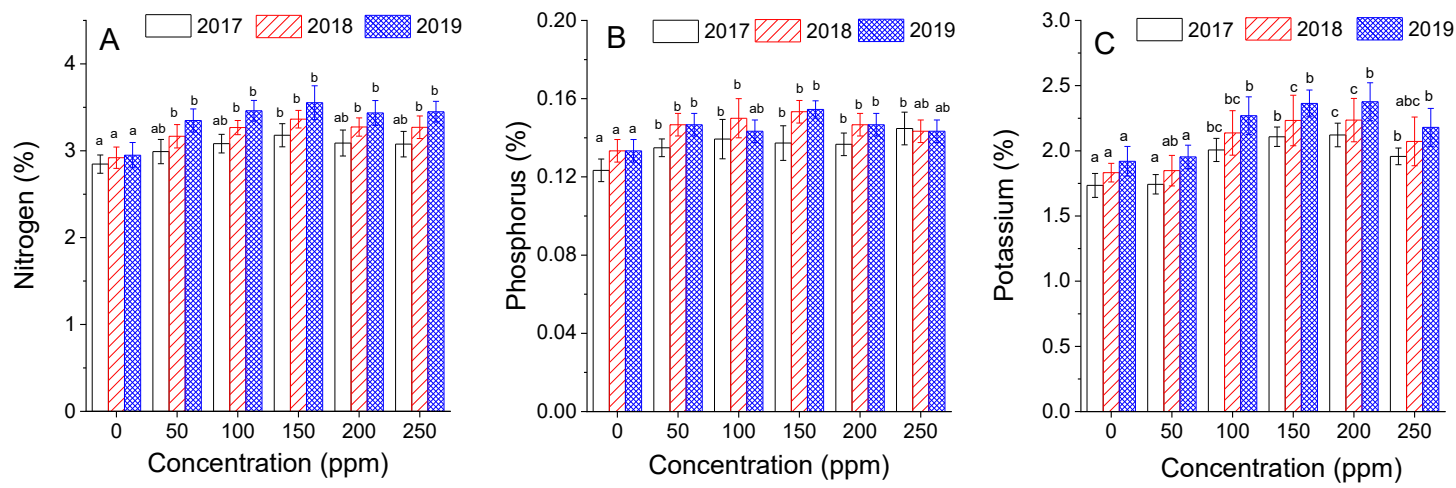

FIGURE 3. Influence of OC concentrations on nitrogen (A), phosphorus (B) and potassium (C) uptakes in coffee leaves for years 2017-2019. Bars represent mean values of three replicates \pm standard deviation. Different letters indicate significant differences $(\mathrm{P}<0.05)$

\section{EFFECT OF OC ON VEGETATIVE GROWTH}

Increase in nutrient uptake and photosynthesis causing a high accumulation of the nutrients in different parts of plants can lead to enhancement of vegetative growth and yields. It is well-known in biological activity that flowering and fruiting of coffee plants do not occur at old nodes (Campanha et al. 2004). Thus, fruit yield of coffee plants in the next years strongly relates to formation of plagiotropic branches and productive nodes in six months. In the present work, the principle parameters including plagiotropic branch length and number of productive nodes were selected to evaluate the vegetative development.

Figure 4 shows that the foliar application of OC might increase length of plagiotropic branches and number of new fruiting nodes on the branches at all the applied concentrations. It is clear that significant difference of plants treated OC with high concentrations (100-250 ppm) compared to the control plants was observed, and maximum values were found to relate to the plants treated in the range of 150-200 ppm. In three years, the increase in plagiotropic branch length $(22.5 \%, 21.4 \%$ and $21.3 \%$, respectively) of plants treated with $\mathrm{OC}$ concentration of $150 \mathrm{ppm}$ was higher than those treated with $200 \mathrm{ppm}$ (19.1\%, 19.1\% and $19.0 \%$, respectively) whereas the increase in number of productive nodes of plants treated with OC concentration at $150 \mathrm{ppm}(18.7 \%, 21.1 \%$, $22.5 \%$, respectively) was lower than those treated with $200 \mathrm{ppm}(26.4 \%, 26.3 \%, 28.4 \%$, respectively).

The OC promoting development characters of coffee plants is similarly to growth of other plants. For instance, the OC was reported to increase $47 \%$ in height of Eucalyptus globulus trees cultivated for three years (Castro et al. 2012). Similarly, OC induced the increase of $10.06 \%$ in height of chickpea and $3.25 \%$ in height of maize (Bi et al. 2011). The result from this study was also 
similar to effect of oligochitosan application on coffee plant reported by Dzung et al. (2011) who showed the productive branches to increase by $19.28 \%$ at applied concentration $60 \mathrm{ppm}$.
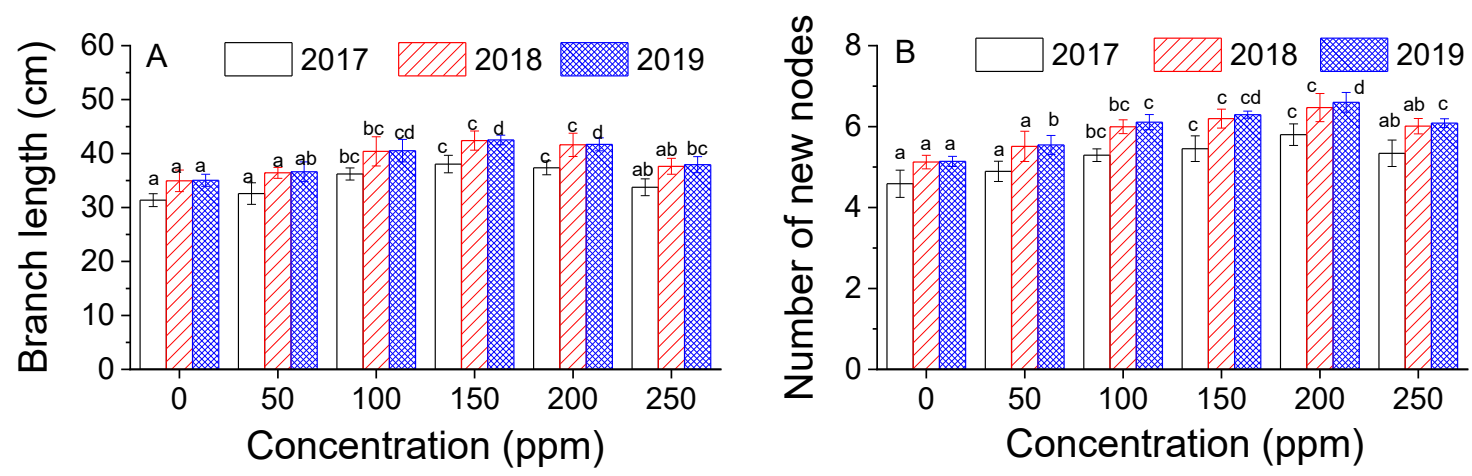

FIGURE 4. Influence of OC concentrations on length of plagiotropic branches (A) and number of new nodes formed during six months (B) for years 2017-2019. Bars represent mean values of three replicates \pm standard deviation. Different letters indicate significant differences $(\mathrm{P}<0.05)$

\section{EFFECT OF OC ON FRESH FRUITS AND FF/DB RATIO}

Better metabolic process and nutrient absorption in the plants during the flowering and fruiting stage regularly affect the fresh fruit weight and FF/DB ratio. However, the different trends were observed in this study (Figure 5 ), where increase of fresh fruit weight and decrease of $\mathrm{FF} / \mathrm{DB}$ ratio were recorded by increase of applied OC concentration.

The greatest increase compared to the control for both parameters was found at concentrations 150 and $200 \mathrm{ppm}$. The values did not differ significantly between applied OC concentrations at 150 and $200 \mathrm{ppm}$. In three years (2017-2019), the plants treated with OC at concentration
$150 \mathrm{ppm}$ compared to control achieved increase of fresh fruit weight by $10.9 \%, 15.6 \%, 15.7 \%$, respectively, and decrease of FF/DB by $3.9 \%, 4.12 \%, 4.13 \%$, respectively. Data showed that increase in the weight of fresh fruits in two years 2018-2019 was similar and higher than those in the first year, 2017. It is confirmed that OC treatment not only strongly effected on the fruit weight in the treated year but promoted growth of the plant for the next years. This is an important factor for growth of perennial crops. These results are in agreement with the previous reports for other crops. Application of OC enhanced productivity and increased weight of seeds by $8-20 \%$ for peanut and by $12.7 \%$ for mungbean (Gatan et al. 2019).
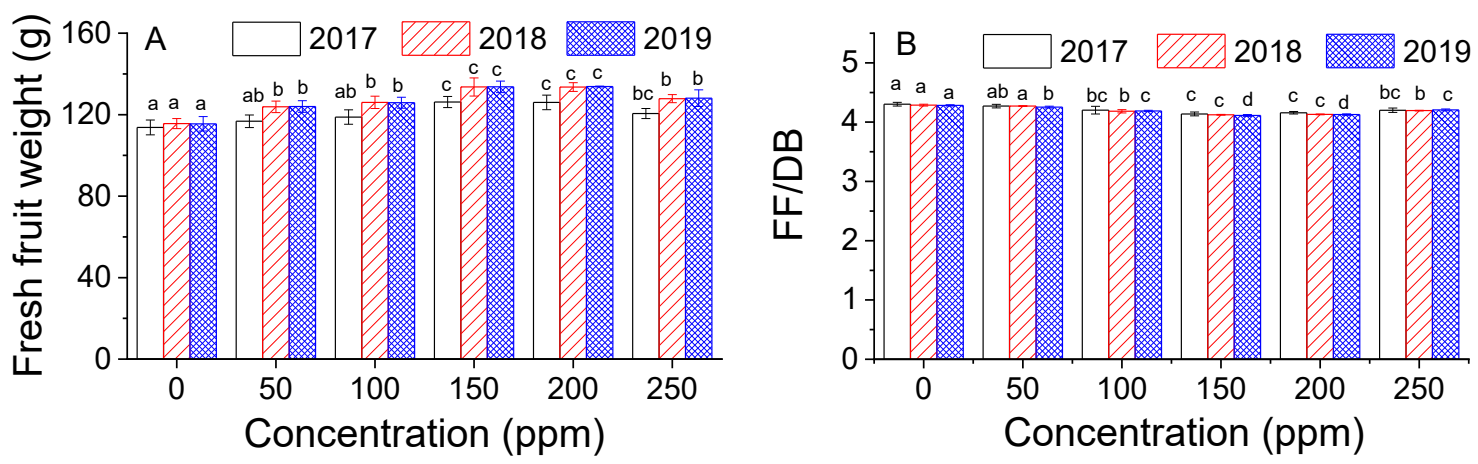

FIGURE 5. Influence of OC concentrations on weight of fresh fruits (A) and ratio of fresh fruit to dry bean (FF/DB) (B) for years 2017-2019. Bars represent mean values of three replicates \pm standard deviation. Different letters indicate significant differences $(\mathrm{P}<0.05)$ 


\section{EFFECT OF OC ON CROP YIELD AND BEAN SIZE}

Increase in chlorophyll content and nutrient uptake can improve plant growth as well as crop productivity and quality. The farming efficiency was evaluated via two principle factors including the bean yield and size that are well known as quantity and quality characters of coffee beans, respectively. Data for effect of OC concentrations on these factors was collected in three years (Figure 6). The result showed significant increase in bean yields after spraying OC with different concentrations. During three years, productivity of coffee beans was gradually increasing in low concentration range of $0-150 \mathrm{ppm}$ and decreasing in high concentration range of 150-250 ppm. A maximum value of coffee yield was obtained at sprayed OC concentration $150 \mathrm{ppm}$. The mean values of bean yield at OC concentration $150 \mathrm{ppm}$ was found to be 3.51 ton ha $^{-1}$ (increased by $13.2 \%$ ) in $2017 ; 3.59$ ton $\mathrm{ha}^{-1}$ (increased by $18.9 \%$ ) in 2018 and 3.75 ton ha ${ }^{-1}$ (increased by $19.8 \%$ ) in 2019 . This result also showed that the increase in coffee yield compared to the control of the next year was higher than the previous year (2019>2018>2017). Meanwhile, coffee yield of the control did not change significantly during three years (3.10 ton ha ${ }^{-1}$ in 2017, 3.02 ton ha ${ }^{-1}$ in 2018 and 3.13 ton $\mathrm{ha}^{-1}$ in 2019). This indicates that OC can enhance crop yield as well as plant growth in the long time. This is an important factor for perennial crops like coffee, a plant with a harvesting period up to 20 years.

Figure 6(B) shows that coffee plants treated with OC concentration $150 \mathrm{ppm}$ exhibited a large size of coffee beans. Increase in bean size with treated time was also observed for all applied concentrations. The percentage of coffee beans with size $>6.3 \mathrm{~mm}$ (class A size) increased compared to the control by $22.44 \%$ in $2017,25.91 .5 \%$ in 2018 , and $29.02 \%$ in 2019 . An optimized OC concentration applied on various crops to achieve the best crops yield has been reported in various studies. Abad et al. (2018a, 2018b, 2016) found optimal OC concentration for pechay at $60 \mathrm{ppm}$, rice at $200 \mathrm{ppm}$ and peanut at $100 \mathrm{ppm}$, and the best OC concentrations determined for peppermint and Pinus radiata were at 80 and 1000 ppm, respectively (Ahmad et al. 2019; González et al. 2013). The various optimal concentrations reported for different plants can relate to biological characteristics of each crop, oligo preparation method, molecular weight of OC, spraying cycle, and number of sprays.

The data also showed that coffee yield in the control plots in 2018 significantly reduced compared to the other years. It can be due to no rain in January-February 2018 (Figure 1). However, coffee yield in 2018 with OC treated at concentration $150 \mathrm{ppm}$ increased compared to the control by $18.9 \%$, much higher than the increase in $2017(13.2 \%)$. The finding is in agreement with the study of lemongrass under various water stress regimes (Singh et al. 2017). It showed that the plants with OC treatment mitigated the harmful effects of drought stress and significantly improved the biochemical plant characteristics and quality because OC possibly induced closure of plant stomata and subsequently reduced the water vapor through leaves.
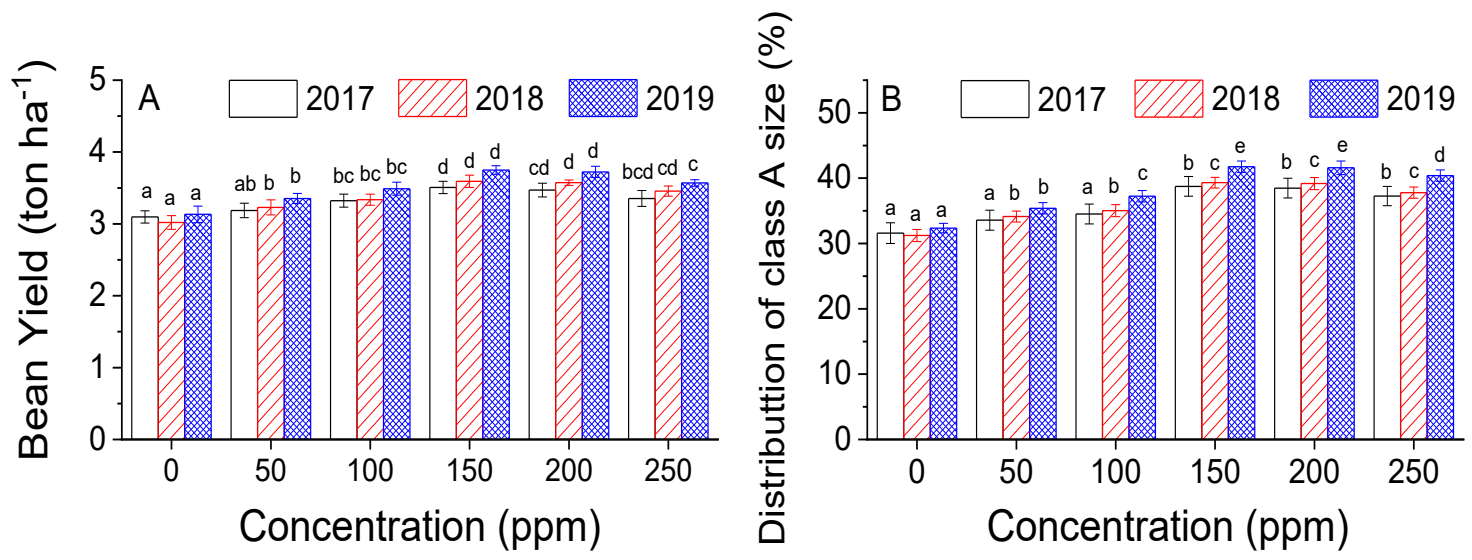

FIGURE 6. Influence of OC concentrations on coffee bean yield (A) and Distribution of class bean A size (B) for years 2017-2019. Bars represent mean values of three replicates \pm standard deviation. Different letters indicate significant differences $(\mathrm{P}<0.05)$ 


\section{CONCLUSION}

Low molecular weight $\kappa$-oligocarrageenan $(4.0 \mathrm{kDa})$ was prepared by a green chemical method using ascorbic acid as a reagent. Results of foliar application on coffee plants showed that OC promoted the vegetative growth of coffee plants through enhancement of photosynthesis, nutrient uptake and increase of coffee crop yield and bean size. The OC concentration had an unambiguous influence on coffee development and yield. The suitable OC concentrations for development of coffee plants were determined in the range of $150-200 \mathrm{ppm}$, and the optimal value was found to be at concentration $150 \mathrm{ppm}$. The influence of OCs on the other crops and extended evaluation of parameters such as spraying time, periods of sprays per year is investigated in our on-going program.

\section{ACKNOWLEDGEMENTS}

This research was funded by Vietnam Academy of Science and Technology, grant 283 number TN18/C06Central Highlands Program 3.

\section{REFERENCES}

Abad, L.V., Aurigue, F.B., Montefalcon, D.R.V., Manguiat, P.H., Carandang, F.F., Mabborang, S.A., Hizon, M.G.S. \& Abella, M.E.S. 2018a. Effect of radiation-modified kappacarrageenan as plant growth promoter on peanut (Arachis hypogaea L.). Radiat. Phys. Chem. 153: 239-244.

Abad, L.V., Dean, G.F.O., Magsino, G.L., Cruz, R.M.M.D., Tecson, M.G., Abella, M.E.S. \& Hizon, M.G.S. 2018b. Semi-commercial scale production of carrageenan plant growth promoter by E-beam technology. Radiat. Phys. Chem. 143: 53-58.

Abad, L.V., Aurigue, F.B., Relleve, L.S., Montefalcon, D.R.V. \& Lopez, G.E.P. 2016. Characterization of low molecular weight fragments from gamma irradiated $\kappa$-carrageenan used as plant growth promoter. Radiat. Phys. Chem. 118: 75-80.

Ahmad, B., Jahan, A., Sadiq, Y., Shabbir, A., Jaleel, H. \& Khan, M.M.A. 2019. Radiation-mediated molecular weight reduction and structural modification in carrageenan potentiates improved photosynthesis and secondary metabolism in peppermint (Mentha piperita L.). Inter. J. Biol. Macromol. 124: 1069-1079.

Bi, F., Iqbal, S., Arman, M., Ali, A. \& Hassan, M. 2011. Carrageenan as an elicitor of induced secondary metabolites and its effects on various growth characters of chickpea and maize plants. J. Saudi Chem. Soc. 15: 269-273.

Bongalos, J., Duna, L., Tigbao, J. \& Aurigue, F. 2019. Radiationmodified kappa-carrageenan improves productivity of peanut (Arachis hypogaea L.) in Bukidnon, northern Mindanao, Philippines. Philip. J. Sci. 149: 101-105.
Campanha, M.M., Santos, R.H.S., Freitas, G.B.D., Martinez, H.E.P., Garcia, S.L.R. \& Finger, F.L. 2004. Growth and yield of coffee plants in agroforestry and monoculture systems in Minas Gerais, Brazil. Agrofor. Syst. 63: 75-82

Carroll, M.J., Slaughter, L.H. \& Krouse, J.M. 1994. Turgor potential and osmotic constituents of Kentucky bluegrass leaves supplied with four levels of potassium. Agron. J. 86: 1079-1083.

Castro, J., Vera, J., González, A. \& Moenne, A. 2012. Oligo-carrageenans stimulate growth by enhancing photosynthesis, basal metabolism, and cell cycle in tobacco plants (var. Burley). J. Plant Growth Regul. 31: 173-185.

Chapman, H.D. \& Pratt, P.F. 1962. Methods of analysis for soils, plants and waters. Soil Sci. 93: 68.

Cottenie, A., Verloo, M. \& Kiekens, L. 1982. Chemical Analysis of Plants and Soils. Gent: RUG. Laboratory of Analytical and Agrochemistry. p. 63.

Dias, K.G.D.L., Guimarães, P.T.G., Neto, A.E.F., Silveira, H.R.O.D. \& Lacerda, J.J.D.J. 2017. Effect of magnesium on gas exchange and photosynthetic efficiency of coffee plants grown under different light levels. Agriculture 7(10): 85.

Dzung, N.A., Khanh, V.T.P. \& Dzung, T.T. 2011. Research on impact of chitosan oligomers on biophysical characteristics, growth, development and drought resistance of coffee. Carbohydr. Polym. 84: 751-755.

Gatan, M.G.B., Recto, D., Montefalcon, V., Aurigue, F.B. \& Abad, L.V. 2019. Effect of radiation modified kappa carrageenan on mungbean. Philip. J. Sci. 149: 35-143.

German, P.U.J., Rey, C.N., Fredisminda, M.D., Matt, E.S.A., Mark, G.S.H. \& Sancho, A.M. 2020. Effects of radiation modified kappa carrageenans supplemention in corn (Zea mays L.). J. Crit. Rev. 7: 6-8.

González, A., Contreras, R.A. \& Moenne, A. 2013. Oligocarrageenans enhance growth and contents of cellulose, essential oils and polyphenolic compounds in Eucalyptus globulus trees. Molecules 18: 8740-8751.

Guilli, M.E., Hamza, A., Clément, C., Ibriz, M. \& Barka, E.A. 2016. Effectiveness of postharvest treatment with chitosan to control citrus green mold. Agriculture 6(2): 12.

Jaramillo-Botero, C., Santos, R.H.S., Martinez, H.E.P., Cecon, P.R. \& Fardin, M.P. 2010. Production and vegetative growth of coffee trees under fertilization and shade levels. Sci. Agric. (Piracicaba, Braz.) 67: 639-645.

Moran, R. 1982. Formulae for determination of chlorophyllous pigments extracted with N,N-dimethylformamide. Plant Physiol. 69: 1376.

Munoz, A.M., Ponce, J.C. \& Araya, J.V. 2011. Method to stimulate carbon fixation in plants with an aqueous solution of oligocarrageenans selected from kappa1, kappa2, lambda or iota, US patent, US20110099898A1

Naeem, M., Idrees, M., Aftab, T., Moinuddin, A.S. \& Varshney, L. 2012. Depolymerised carrageenan enhances physiological activities and menthol production in Mentha arvensis L. Carbohydr. Polym. 87: 1211-1218. 
Salamanca-Jimenez, A., Doane, T.A. \& Horwath, W.R. 2017. Nitrogen use efficiency of coffee at the vegetative stage as influenced by fertilizer application method. Front. Plant Sci. 8: 223-223.

Salachna, P., Grzeszczuk, M., Meller, E. \& Soból, M. 2018. Oligo-alginate with low molecular mass improves growth and physiological activity of Eucomis autumnalis under salinity stress. Molecules 23(4): 812.

San, P.T., Khanh, C.M., Khanh, H.H.N., Khoa, T.A., Hoang, N., Nhung, L.T., Trinh, N.T.K. \& Nguyen, T.D. 2020. $k$-Oligocarrageenan promoting growth of hybrid maize: Influence of molecular weight. Molecules 25(17): 3825.

Saucedo, S., Contreras, R.A. \& Moenne, A. 2015. Oligocarrageenan kappa increases $\mathrm{C}, \mathrm{N}$ and $\mathrm{S}$ assimilation, auxin and gibberellin contents, and growth in Pinus radiata trees. J. For. Res. 26: 635-640.

Singh, M., Khan, M.M., Uddin, M., Naeem, M. \& Qureshi, M.I. 2017. Proliferating effect of radiolytically depolymerized carrageenan on physiological attributes, plant water relation parameters, essential oil production and active constituents of Cymbopogon flexuosus Steud. under drought stress. PLoS ONE 12: e0180129.

Stadnik, M.J. \& Freitas, M.B.D. 2014. Algal polysaccharides as source of plant resistance inducers. Trop. Plant Pathol. 39: 111-118.

Walling, L.L. 2000. The myriad plant responses to herbivores. J. Plant Growth Regul. 19: 195-216.
Xia, W., Liu, P., Zhang, J. \& Chen, J. 2011. Biological activities of chitosan and chitooligosaccharides. Food Hydrocoll. 25: 170-179.

Xu, L. \& Geelen, D. 2018. Developing biostimulants from agrofood and industrial by-products. Front. Plant Sci. 9: 1567.

Zulfiqar, F., Casadesús, A., Brockman, H. \& Munné-Bosch, S. 2020. An overview of plant-based natural biostimulants for sustainable horticulture with a particular focus on moringa leaf extracts. Plant Sci. 295: 110194.

Pham Trung San, Chau Minh Khanh, Huynh Hoang Nhu Khanh*, Truong Anh Khoa, Nguyen Hoang \& Pham Duc Thinh

NhaTrang Institute of Technology Research and Application

Vietnam Academy of Science and Technology

NhaTrang City

Vietnam

Thanh-Danh Nguyen

Institute of Chemical Technology

Vietnam Academy of Science and Technology

Ho Chi Minh City

Vietnam

*Corresponding author; email: khanhhuynh@nitra.vast.vn

Received: 13 September 2020

Accepted: 11 March 2021 